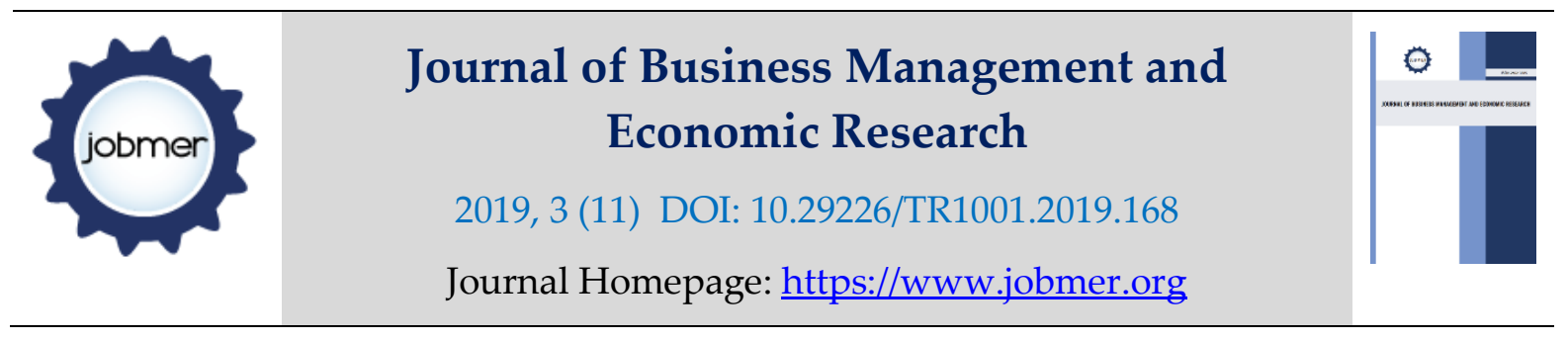

\title{
INCOME DIVERSIFICATION AND PERFORMANCE: SHOULD BANKS TRADE?
}

\author{
Peter Nderitu GITHAIGA \\ Moi University, Po BOX 3900-30100 Eldoret, Kenya \\ Josephat Cheboi YEGON \\ Moi University, Po BOX 3900-30100 Eldoret, Kenya \\ Joyce Kimosop KOMEN \\ Moi University, Po BOX 3900-30100 Eldoret, Kenya
}

\begin{abstract}
Unprecedented growth in financial innovations, changing customers' expectations, competition from nonbanking entities and regulatory pressure have distorted interest income stream. Thus, banks are now searching for new ways of income generation to cushion themselves against dwindling interest income and as a survival strategy. Proponents of portfolio theory conjecture that income diversification reduces income volatility and increase the profitability. It's from this background the study sought to investigate the effect of income diversification on performance of Kenyan commercial banks.

Using 310 observations drawn from a sample of 31 commercial banks and panel data for the period 20082017, the study found that income diversification has a positive and significant effect on bank performance. Therefore, commercial banks are advised to consider investing in non-lending activities to better their financial performance. In view of this, the study has implications for bank regulators, scholars and practitioners
\end{abstract}

Key words: Income diversification, non-interest income, performance, Herfindahl-Hirschman Index

\section{Introduction}

The banking sector is important to practitioners and the regulator due to its influence on macro-economic factors such as economic growth (Tongurai \&Vithessonthi, 2018; Balcilar et al., 2018), entrepreneurship (Toms \& Wright 2019, Cai et al., 2018; Khan \& Anuar, 2018), resource allocation (Beck et al., 2007; Dwyer, 
2018), poverty alleviation(Honohan, 2004; Abdin, 2016; Sikod \& Baye, 2015), education (Sun \& Yannelis, 2016; Goksu \& Goksu, 2015) and agriculture (Anetor et al.,2016; Bustos et al., 2016). Moreover, monetary authorities transmit macroeconomic policies through the financial system rendering the banking sector one of the highly regulated sector (Valla et al., 2006). Thus, an underperforming banking sector derails economic growth through reduced capital investment on production of goods and services (Sufian \& Chong, 2008; Dietrich \& Wanzenried, 2014).

Studies show that the global banking sector continues to grapple with numerous performance impediments ranging from rising non-performing loans, stringent regulations to technological revolution (Gololo, 2018; Dimitrios \& Mike, 2016; Psillaki \& Mamatzakis, 2017). According to IMF reports (2007-2017), the sector reported an insignificant growth in the last decade as evidenced by the average return on asset for example U.S. $(0.2 \%$, 2007; 0.3\%, 2017), Japan $(0.3 \%, 2007 ; 0.2 \%$, 2017), China $(0.6 \%, 2007 ; 1.0 \%$, 2017), South Africa (1.6\%, 2007; 1.7\%, 2017), Ghana (3.2\%, 2007; 4.3\%, 2017) and Kenya (3.9\%, 2007; 3.2\%, 2017). Additionally, Kenya witnessed the collapse of three banks namely Dubai Bank, Imperial Bank and Chase Bank, because of corporate governance mishaps, insolvency and overly non-performing loans (CBK, 2017).

Researchers have singled out non-performing loans as a major cause of banks failure (Laryea et al., 2016; Waweru \& Kalani, 2009; Fofack, 2005; Mwega, 2009; Zhang et al., 2016). During the period 2007-2017 the ratio of non-performing loans to gross loans and advances stood at U.S. (0.5\%, 2007; $1.1 \%$, 2017), Japan (1.4 $\%$, 2007; 1.2\%, 2017), China (1.2\%, 2007; 0.7, 2017), South Africa (3.9 \% , 2007; $3.8 \%$,2017), Ghana (7.7\%, 2007; $21.6 \%$, 2017) and Kenya (16.2 \% ,2007; 9.2\% ,2017) (IMF 2007; 2017). Between 1986 and 1998, 37 banks collapsed in Kenya due to non-performing loans (Waweru \& Kalani, 2009; Mwega, 2009). Taking into account the high level of non-performing loans and the average return on assets it is evident that the lending business is ailing and with a bleak future hence banks ought to consider engaging in nonlending activities for survival.

In Kenya, the situation has been exacerbated by the enactment of interest capping law that limits lending rates to 4 per cent above the central bank base lending rate (Banking Act (Amendment) 2016). Olaka (2017) noted that interest capping created a fertile ground for informal lending besides a noticeable decline in individual lending that is likely to crowd out credit to private sector. Researcher claim that interest capping and competition distorts interest income and banks must now shift focus on new income generating activities away from financial intermediation for survival (Ferrari et al., 2018; Mohamed \& Bett, 2018; Ng'ang'a, 2019). Moreover, Kenyan banks have lost a significant size of their business to telecommunication companies, mainly Safaricom Ltd, engaging in money transfers and mobile loans in 
addition to mobile loan apps (Paelo, 2014; Mudavadi \& Weber, 2013). Against this background the study sought to examine the effect of income diversification on performance in the Kenyan banking sector. Furthermore, most of the previous studies focused on developed and emerging economies (Abedifar et al., 2014; Chen et al., 2017; Hahm, 2008)

\section{Literature Review and Theoretical Foundation}

\subsection{Income Diversification}

Income diversification refers to increasing the share of fee, net trading profits and other noninterest income within net operating income of a bank (Gurbuz et al., 2013). Moreover, Ebrahim and Hasan (2008) view income diversification as an expansion into new income earning financial services save for traditional intermediation services. In principle, income diversification is a shift from lending activities towards nonlending activities such as investment banking, trading and insurance (Busch \& Kick, 2009).

According to Mujeri and Younus (2009), banks can widen and stabilize their income base by engaging in advisory, asset management services, and sale of insurance and mutual fund products, payment products, electronic bill payments and sale of credit cards. Borrowing from portfolio theory, non-interest income and interest income are uncorrelated thus, income diversification leads to income stability. DeYoung and Rice (2004) found that non-interest income accounted for approximately $40 \%$ of the banks total operating income.

\subsection{Theoretical Foundation}

The theoretical foundation of income diversification is Markowitz (1952) Modern Portfolio Theory. The theory postulates that banks can reduce income volatility and improve overall financial performance by engaging in a range of income generating activities (Matthies, 2014). Banks diversify their income by venturing into non-lending activities such as investment banking, advisory, brokerage and underwriting (Saunders et al., 2016).

Moreover, Sanya and Wolfe (2011) claim that income diversification absorbs the impact of information asymmetry through cross selling while cushioning banks against cyclical variation in interest revenue. Similarly, Khanna and Tice (2001) opine that diversified firms make optimal investment decisions unlike focused firms. Besides, Williamson (1986) opines that by holding a diversified portfolio of assets, a bank is able to cushion depositors from any possible losses arising from delegated monitoring. Additionally, 
Winton (1997) posits that in a highly competitive market, diversification improves the quality of service banks offer their customer.

According to Chiorazzo et al (2008), income diversification leads to economies of scale and scope owing to shared production in delivery of related financial. Landskroner et al., (2005) infer that income diversification improves bank revenue and operational efficiency especially where the scale and scope of operations expands. Consistent with portfolio theory, it can be argued that income diversification contribute to stable revenues and greater firm longevity (Fang \& Lelyveld, 2014; Schoenmaker \& Wagner, 2011; Berger et al., 2010). Castaldi and Giarratana (2014) and Matsusaka (2001) assert that diversification leverages utilization and preservation of firms' knowledge resources. Implying that income diversification is a strategy through which banks create value from intellectual capital for competitive advantage.

\subsection{Income Diversification and Firm performance}

Previous studies show that firms pursue income diversification in order to accomplish varied strategic objectives such as internal capital market efficiency (Shih et al., 2018), competitive advantage (Montgomery \& Wernerfelt, 1988), shareholder value (Bernardo \& Chowdhry, 2002), managerial entrenchment (Cheng \& Keung, 2018), economies of scale (Beccalli et al., 2015), resource utilization (Alhassan \& Tetteh, 2017), crosssubsidization (Lepetit et al., 2008), lower bank spread (Mujeri \& Younus, 2009), market power (Ovi et al., 2014) and enhanced performance (Sanya \& Wolfe, 2011).

However, through intermediation, banks earn interest revenue by attracting time and demand deposits from households and firms then repackaging such deposits into loans and other forms of advances (Craigwell \& Maxwell, 2009). Studies show that competition, unprecedented financial innovations and regulatory pressure have adversely affected interest income forcing banks to engaging in nonlending activities for profit and survival (DeYoung \& Rice, 2004).

Non-interest income consists of fee and non-fee incomes. Activities that generate fees income include loan processing, bill discounting, letters of credit and guarantee, account keeping, service and management (Lepetit et al., 2008; DeYoung \& Roland, 2001). While non-fee income arises from foreign exchange transactions, investment in government and corporate securities, rental premises owned by the bank and gains from the sale of premises (Rushdi \& Tennant, 2003).

In spite of the unprecedented appetite for non-lending activities, the debate on whether income diversification improves financial performance continues to widen. Some studies claim that income diversification improve performance (Jen Huang \& Cheng 2006), reduces risk exposure (Saunders et al., 
2016, Abedifar et al., 2014; Calmès \& Théoret, 2015), lowers banks spread (Mujeri \& Younus, 2009; Kannan et al., 2001), increases market power (Ovi et al., 2014) and enhances firm productivity (Alhassan \& Tetteh, 2017)

Conversely, there are studies claiming that income diversification reduces profitability besides exposing banks to income volatility (DeYoung \& Roland, 2001; Delpachitra \& Lester 2013; Chen et al, 2017; DemirgüçKunt \& Huizinga, 2009). Surprisingly, there exist studies arguing that income diversification has no significant effect on bank performance hence banks should focus on traditional activities (Hahm, 2008).

There are several explanations for the endless debate around income diversification and bank performance causality. First, interest income is earned through relationship based activities with high switching cost compared to fee-based transactions which occasionally are one-off hence the benefits of diversification are short-term (DeYoung \& Rice, 2003). Second, nonlending activities are likely to impact adversely on banks operating and financial leverage thus lessening diversification gains (DeYoung \& Rice, 2003). Third, through cross-subsidization and cross selling the effect of income diversification might be invisible (Lepetit et al., 2008). Fourth, income diversification is likely to breed lazy banks (Kumhof \& Tanner, 2005; Kumar \& Hauner, 2006; Hauner, 2008). Based on empirical literature and portfolio theory the study's hypotheses are derived as follows,

\section{Ho: Income Diversification has no significant effect on performance}

$H_{a}$ : Income Diversification has a significant effect on performance

\section{Research Design}

According to Zikmund et al., (2013) research design denotes methods and procedures for collecting and analyzing the needed information comprising of sampling methodologies, data collection techniques, data analysis and cost schedules. This research is both longitudinal and explanatory. A longitudinal study uses continuous or repeated measures to follow specific individuals over an extended period of time (Caruana, 2017). In this study, the variables will be examined over the period between 2008 and 2017. Saunders et al., (2011) affirms that explanatory studies seek to establish causal relationship between variables with main emphasis being to study a problem in order to explain the relationship between variables.

\subsection{Study Population}

The study population comprised of 42 commercial banks and 1 mortgage finance company (CBK, 2016). The inclusion and exclusion criterion was guided by whether or not the bank was in operation between 2008 and 2017. Only 31 banks qualified for further analysis. The data collected was secondary and 
quantitative in nature. Data was analyzed through descriptive and inferential statistics. Specifically, the data was summarized through mean and standard deviations. Correlation analysis was used to establish the nature and magnitude of the relationship between while multiple regression analysis was used to test the research hypothesis.

\subsection{Measurement of Variables}

The study had five variables namely; the dependent variable (firm performance), independent variable (income diversification) and control variable (firm size, firm age and lending strategy) as illustrated by a conceptual framework below

Independent Variable

\begin{tabular}{|l|l|}
\hline $\begin{array}{l}\text { Income } \\
\text { Diversification }\end{array}$ & Firm Performance \\
& \\
\hline
\end{tabular}

- Firm Size

- Firm Age

- Lending Strategy

Fig 1: Conceptual framework (Source Authors; 2019)

Financial performance was measured as return on assets, which is the ratio of firm's net earnings to total assets. ROA shows the extent to which a firm is utilizing its assets. A high ROA means that the firm is utilizing its assets efficiently and for value (Van Vu et al., 2018; Juma \& Atheru, 2018; Eklof et al., 2018). ROA is computed as the ratio of net income/ profit to total assets. Banks' operating income comprise of interest income generated from lending activities and non-interest income earned from nonlending activities. The standard measure of income diversification is Herfindahl-Hirschman Index (Jouida, 2018; Olarewaju, 2018; Nepali, 2018; Batool \& Jamil, 2019; Brahmana et al., 2018). The study adopted Herfindahl Hirschman Index (HHI) as the measure for income diversification. HHI is computed as follows;

$$
\mathrm{HHI}=\left\{(\mathrm{NII} / \mathrm{NOI})^{2}+(\mathrm{NONI} / \mathrm{NOI})^{2}\right\}
$$


Income Diversification (INDIV) $=\{1-\mathrm{HHI}\}$

Where;

NII: Amount of net interest income

NONII: Amount of non-interest income

NOI: Net operating income

HHI varies between 0 and 1.00 . HHI of 0.50 shows average income diversification while HHI closer to 1.00 represents the highest level of income diversification As HHI increases the bank becomes more diversified. Hence the lower the value of $\mathrm{HHI}$ the more concentrated the firm is

The study controlled for factors that are likely to affect the endogenous variable to rule out alternative explanation and enhance the predictive power of the exogenous variable and the mediator. Specifically, the control variable comprised of;

i) Firm age has an impact on financial performance. This variable was measured as the number of years since incorporation of the firm. (Lei \& Chen, 2019; Ilaboya and Ohiokha, 2016)

Firm Age $(\mathrm{FA})=$ Number of years since incorporation

ii) Firm size measured as natural logarithm of total bank assets (Wan \& Zhang, 2018; PuchetaMartínez et al., 2019; Chiorazzo et al., 2008). Large banks have more resources and opportunities for diversification compared to smaller banks.

Firm Size (FS) = Logarithm Total Assets

iii) Lending Strategy denoted as ratio of total loans to total assets (Edirisuriya et al., 2015; Gurbuz et al., 2013; Buch et al., 2019). This variable controls for the effects of lending strategy on risk-adjusted bank performance

\subsection{Research model}

The study used panel data for the period between 2008 and 2017. Panel data consist of observations on $n$ and $t$ years. The relationship between variables was examined through regression analysis as shown below;

$\mathrm{FP}_{\mathrm{it}}=\beta_{0}+\beta_{1} \mathrm{INDIV}_{\mathrm{it}}+\beta_{2} \mathrm{FA}_{\mathrm{it}}+\beta_{3} \mathrm{FS}_{\mathrm{it}}+\beta_{4} \mathrm{LS} \mathrm{Sit}_{\mathrm{it}}+\varepsilon_{\mathrm{it}}$

Where;

FP= Firm Performance

INDIV= Income Diversification

FA= Firm Age 


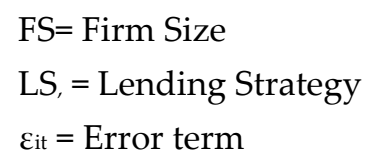

\section{Results and Discussion}

Table I: Summary Descriptive Statistics of Research Variable

\begin{tabular}{llllll}
\hline Variable & Obs & Mean & Min & Max & Std. Dev \\
\hline \hline Firm Performance & 310 & 0.03 & 0.00 & 0.10 & 0.018354 \\
INDIV & 310 & 0.40 & 0.00 & 0.51 & 0.0915641 \\
Lending Strategy & 310 & 0.57 & 0.02 & 0.86 & 0.1216674 \\
Firm Size & 310 & 76600000000 & 2289000000 & 556000000000 & 96200000000 \\
Firm Age & 310 & 34.82 & 1.00 & 121.00 & 29.22061 \\
\hline \hline
\end{tabular}

Source: Author 2019

Table II: Results of Correlation Analysis

\begin{tabular}{llllll}
\hline \hline & FP & INDIV & FA & FS & LS \\
\hline \hline Firm Performance (FP) & 1 & & & & \\
Income Diversification(INDV) & $.699^{* *}$ & 1 & & & \\
Firm Age (FA) & $.294^{* *}$ & $.177^{* *}$ & 1 & & \\
Firm Size(FS) & $.372^{* *}$ & $.210^{* *}$ & $.542^{* *}$ & 1 & \\
Lending Strategy (LS) & $-.122^{*}$ & -0.104 & -0.056 & -0.032 & 1 \\
\hline \hline
\end{tabular}

** Correlation is significant at the 0.01 level (2-tailed).

* Correlation is significant at the 0.05 level (2-tailed).

Source: Author 2019

Table III: Results of Regression Analysis

\begin{tabular}{lrrrr}
\hline \hline \multicolumn{1}{c}{ Variable } & Coefficient & Std. Error & t-Statistic & Prob. \\
\hline \hline Constant & -2.123120 & 0.305680 & -6.945559 & 0.0000 \\
Income Diversification & 0.332326 & 0.020073 & 16.55582 & 0.0000 \\
Firm Age & -0.014009 & 0.065723 & -0.213151 & 0.8314 \\
Firm Size & 0.124265 & 0.046308 & 2.683413 & 0.0077 \\
Lending Strategy & -0.326297 & 0.126677 & -2.575827 & 0.0105 \\
\hline \hline & & & & \\
R-squared & 0.498306 & & & \\
Adjusted R-squared & 0.491726 & & & \\
S.E. of regression & 0.217604 & & & \\
F-statistic & 75.73509 & & & \\
\end{tabular}


Prob(F-statistic) $\quad 0.000000$

Number of Observations $\quad 310$

Source: Researcher, 2019

Table I illustrates summary statistics for the research variables. Table II shows the results of pairwise correlation analysis while Table III shows the results of the random effect regression analysis. Before analysis the data was log transformed then tested for unit root, heteroskedasticity and autocorrelation and it was found suitable for regression analysis. The results of the Hausman test favoured random effect regression. Table I indicates that the average industry return on asset for the period 2008-2017 was 3\%. Additionally, the table shows that average bank age is 34 years and the mean bank size is Ksh 76.6 billion. Further, the table shows that the average income diversification was 0.40 which can be interpreted as an intermediate level of income diversification.

The results of the pairwise correlation are shown in Table II. The table illustrate that the income diversification and performance is positive and significant $(\mathrm{r}=0.699, \mathrm{Q}<0.01)$. The correlation between firm age and firm performance and significant $(\mathrm{r}=0.294, \mathrm{Q}<0.01)$; same case to firm size and firm performance $(\mathrm{r}=0.372, \mathrm{Q}<0.01)$ as well as firm size and firm age $(\mathrm{r}=0.542 \mathrm{Q}<0.01)$. However, the correlation of the two control variables, firm size and firm age, with process capital was positive though nonsignificant at $1 \%$ and $5 \%$. Table II further revealed that the relationship between bank lending strategy and performance was negative and significant at $1 \%(\mathrm{r}=-0.122, \mathrm{Q}<0.01)$

The main objective of this study was to examine the effect of income diversification firm performance nexus. The regression results showed that the relationship was positive and statistically significant $\left(R^{2}=\right.$ $0.49, \beta=0.332$, $\mathrm{Q}<0.05)$. As a result our null hypothesis that; income diversification has no significant effect on performance is rejected and the alternative hypothesis accepted. One percent change in income diversification lead to $33.2 \%$ change in bank performance. Similarly, firm size had a positive and significant effect on performance $(\beta=0.124, \varrho<0.05)$. Conversely, the findings indicated that firm age $(\beta=-0.014, \varrho>$ $0.05)$ and lending strategy $(\beta=-0.326, \varrho<0.05)$ had an adverse effect on performance. The overall the model predicts $49 \%$ change in performance. Consistent with modern portfolio theory, the study argues that income diversification improves banks financial performance considering banks are facing declining interest income.

These findings are consistent with previous studies by Carroll and Stater (2008), Elsas et al., (2006), Chiorazzo et al., (2008) and Edirisuriya et al., (2015). Income diversification enables banks to broaden revenues streams thus leading to income stability and organizational longevity. Income diversification is associated with efficient internal capital markets, economies of scale, cross selling and cross subsidization that improve firm financial performance.

Accordingly, in an era of interest capping, high competition from non-banking entities and unprecedented growth in financial innovation, banks should consider diversifying into nonlending businesses for competitive advantage and long-term profitability.

\section{Conclusion}


The study developed a conceptual framework through extensive literature review that also aided formulation of research hypotheses. The focus was on income diversification and bank performance. The unit of analysis was commercial banks in Kenya. Th study extracted data from annual financial data from the respective banks and Central Bank of Kenya annual supervisory reports. The findings of this study revealed that income diversification improves firm performance. Nonetheless, the extent banks can engage in non-lending activities is usually limited under banking laws and regulations. Specifically, banks are restricted to activities that either complement or are incidental to lending. Therefore, the study argues that such limit the impact of income diversification on performance. The study recommends that regulatory authorities should relax such regulations to allow banks engage in a wider scope of activities to exploit intellectual capital and ultimately improved performance. Alternatively, the regulator can impose diversification ceilings that are sufficient to cushion banks from interest income volatility. Due to unavailability of data, noninterest income was measured in aggregate form thus prospective researcher can consider decomposing non-interest income into its constituent elements.

\section{References}

Abdin, J. (2016). Financial development and poverty reduction: Exploring the links between the issues using evidence from Bangladesh. International Journal of Financial Research, 7(4), 44-65.

Abedifar, P., Molyneux, P., \& Tarazi, A. (2014). Non-Interest Income Activities and Bank Lending. Working Paper Responsible Banking and Finance, 15-002 2015

Alhassan, A. L., \& Tetteh, M. L. (2017). Non-Interest Income and Bank Efficiency in Ghana: A Two-Stage DEA Bootstrapping Approach. Journal of African Business, 18(1), 124-142.

Anetor, F., Ogbechie, C., Kelikume, I., \& Ikpesu, F. (2016). Credit supply and agricultural production in Nigeria: a vector autoregressive (VAR) approach. Journal of Economics and Sustainable Development, $7(2)$.

Balcilar, M., Gupta, R., Lee, C. C., \& Olasehinde-Williams, G. (2018). The synergistic effect of insurance and banking sector activities on economic growth in Africa. Economic Systems, 42(4), 637-648.

Batool, S., \& Jamil, F. (2019). Rural employment and income diversification in Pakistan. Pakistan Journal of Agricultural Sciences, 56(2).

Beccalli, E., Anolli, M., \& Borello, G. (2015). Are European banks too big? Evidence on economies of scale. Journal of Banking \& Finance, 58, 232-246.

Beck, T., Demirgüç-Kunt, A. and Levine, R (2007) Finance, inequality and the poor, Journal of Economic Growth, 12(1), 27-49

Berger, A. N., Hasan, I., \& Zhou, M. (2010). The effects of focus versus diversification on bank performance: Evidence from Chinese banks. Journal of Banking \& Finance, 34(7), 1417-1435

Bernardo, A. E., \& Chowdhry, B. (2002). Resources, real options, and corporate strategy. Journal of Financial Economics, 63, 211-234.

Brahmana, R., Kontesa, M., \& Gilbert, R. E. (2018). Income diversification and bank performance: evidence from malaysian banks. Economics Bulletin, 38(2), 799-809

Buch, C. M., Krause, T., \& Tonzer, L. (2019). Drivers of systemic risk: Do national and European perspectives differ?. Journal of International Money and Finance, 91, 160-176. 
Busch, R. and Kick, T.. (2009). Income Diversification in the German Banking Industry, Deutsche Bundesbank Euro system. Discussion Paper. Series 2: Banking and Financial Studies. No: 09/2009.

Bustos, P., Garber, G., \& Ponticelli, J. (2016). Capital allocation across sectors: Evidence from a boom in agriculture. Banco Central do Brasil (414).

Cai, D., Song, Q., Ma, S., Dong, Y., \& Xu, Q. (2018). The relationship between credit constraints and household entrepreneurship in China. International Review of Economics \& Finance, 58, 246-258.

Calmès, C., \& Théoret, R. (2015). Product-mix and bank performance: new US and Canadian evidence. Managerial Finance, 41(8), 773-805.

Carroll, D. A., \& Stater, K. J. (2008). Revenue diversification in nonprofit organizations: Does it lead to financial stability?. Journal of public administration research and theory, 19(4), 947-966.

Castaldi, C., \& Giarratana, M. (2014). Diversification, branding and performance of knowledge-intensive service firms. In conference; DRUID Conference 2014.

Caruana, E. J., Roman, M., Hernández-Sánchez, J., \& Solli, P. (2015). Longitudinal studies. Journal of thoracic disease, 7(11), E537

Chen, C. R., Huang, Y. S., \& Zhang, T. (2017). Non-interest Income, trading, and bank risk. Journal of Financial Services Research, 51(1), 19-53.

Chen, G. Z., \& Keung, E. C. (2018). Corporate diversification, institutional investors and internal control quality. Accounting \& Finance, 58(3), 751-786

Chiorazzo, V., Milani, C., \& Salvini, F. (2008). Income diversification and bank performance: Evidence from Italian banks. Journal of Financial Services Research, 33(3), 181-203.

Craigwell, R., \& Maxwell, C. (2006). Non-interest income and financial performance at commercial banks in Barbados. Savings and Development, 309-328.

Delpachitra, S., \& Lester, L. (2013). Non-Interest Income: Are Australian Banks Moving Away from their Traditional Businesses?. Economic Papers: A journal of applied economics and policy, 32(2), 190-199.

Demirgüç-Kunt, A., \& Huizinga, H. (1999). Determinants of commercial bank interest margins and profitability: some international evidence. The World Bank Economic Review, 13(2), 379-408.

DeYoung, R., \& Rice, T. (2004). Noninterest income and financial performance at US commercial banks. Financial Review, 39(1), 101-127.

DeYoung, R., \& Roland, K. P. (2001). Product mix and earnings volatility at commercial banks: Evidence from a degree of total leverage model. Journal of Financial Intermediation, 10(1), 54-84.

Dietrich, A., \& Wanzenried, G. (2014). The determinants of commercial banking profitability in low-, middle-, and high-income countries. The Quarterly Review of Economics and Finance, 54(3), 337-354

Dimitrios, A., Helen, L., \& Mike, T. (2016). Determinants of non-performing loans: Evidence from Euroarea countries. Finance research letters, 18, 116-119

Dwyer, R. E. (2018). Credit, debt, and inequality. Annual Review of Sociology, 44, 237-261.

Ebrahim, A., \& Hasan, I. (2008). The value relevance of product diversification in commercial banks. Review of Accounting and Finance, 7(1), 24-37

Edirisuriya, P., Gunasekarage, A., \& Dempsey, M. (2015). Australian Specific Bank Features and the Impact of Income Diversification on Bank Performance and Risk. Australian Economic Papers, 54(2), 63-87.

Eklof, J., Podkorytova, O., \& Malova, A. (2018). Linking customer satisfaction with financial performance: an empirical study of Scandinavian banks. Total Quality Management \& Business Excellence, 1-19. 
Elsas, R., Hackethal, A., \& Holzhäuser, M. (2010). The anatomy of bank diversification. Journal of Banking $\mathcal{E}$ Finance, 34(6), 1274-1287.

Fang, Y., \& van Lelyveld, I. (2014). Geographic diversification in banking. Journal of Financial Stability, 15, 172-181.

Ferrari, A., Masetti, O., \& Ren, J. (2018). Interest rate caps: the theory and the practice. The World Bank

Goksu, A., \& Goksu, G. G. (2015). A comparative analysis of higher education financing in different countries. Procedia Economics and Finance, 26, 1152-1158.

Gololo, I. A. (2018). Challenges of the Nigerian Banking Sector and the Way Forward. American Finance $\mathcal{E}$ Banking Review, 3(1), 26-34.

Gurbuz, A. O., Yanik, S., \& Ayturk, Y. (2013). Income diversification and bank performance: Evidence from Turkish banking sector. Journal of BRSA Banking and Financial markets, 7(1), 9-29.

Hahm, J. (2008). Non-interest income of commercial banks: evidence from OECD countries. BOK Working Paper 330, The Bank of Korea.

Hauner, D. (2009). Public debt and financial development. Journal of development economics, 88(1), 171-183.

Honohan, P. (2004). Financial development, growth and poverty: how close are the links?. In Financial Development and Economic Growth (pp. 1-37). Palgrave Macmillan, London

Ilaboya, O. J., \& Ohiokha, I. F. (2016). Firm age, Size and Profitability dynamics: A test of learning by doing and structural inertia hypotheses. Business and Management Research, 5(1), 29.

IMF. Financial Soundness Indicators. http://data.imf.org/?sk=51B096FA-2CD2-40C2-8D090699CC1764DA\&sId=1411569045760/2007-2017

Jen Huang, C., \& Ju Liu, C. (2005). Exploration for the relationship between innovation, IT and performance. Journal of Intellectual Capital, 6(2), 237-252.

Jouida, S. (2018). Diversification, capital structure and profitability: A panel VAR approach. Research in International Business and Finance, 45, 243-256

Kannan, R., Narain, A., \& Ghosh, S. (2001). Determinants of net interest margin under regulatory requirements: an econometric study. Economic and political Weekly, 337-344.

Khan, S. J. M., \& Anuar, A. R. (2018). Access to Finance: Exploring Barriers to Entrepreneurship Development in SMEs. In Global Entrepreneurship and New Venture Creation in the Sharing Economy (pp. 92-111). IGI Global.

Khanna, N., \& Tice, S. (2001). The bright side of internal capital markets. The Journal of Finance, 56(4), 14891528

Kumar, M. M. S., \& Hauner, M. D. (2006). Fiscal Policy and Interest Rates: How Sustainable is the" new Economy"? (No. 6-112). International Monetary Fund

Kumhof, M. M., \& Tanner, M. E. (2005). Government debt: A key role in financial intermediation (No. 557). International Monetary Fund.

Landskroner, Y., Ruthenberg, D., \& Zaken, D. (2005). Diversification and performance in banking: The Israeli case. Journal of Financial Services Research, 27(1), 27-49.

Lei, Q., \& Chen, H. (2019). Corporate Governance Boundary, Debt Constraint, and Investment Efficiency. Emerging Markets Finance and Trade, 55(5), 1091-1108

Lepetit, L., Nys, E., Rous, P., \& Tarazi, A. (2008). Bank income structure and risk: An empirical analysis of European banks. Journal of Banking \& Finance, 32(8), 1452-1467. 
Markowitz, H. (1952). Portfolio selection. The journal of finance,7(1), 77-91.

Matsusaka, J. G. (2001). Corporate diversification, value maximization, and organizational capabilities. The Journal of Business, 74(3), 409-431.

Matthies, B. (2014). Process capital: a synthesis of research and future prospects. Knowledge and Process Management, 21(2), 91-102

Mohamed, A. I., \& Bett, S. (2018). Strategic resources and performance of commercial banks in Kenya: Case of Equity Bank Limited. International Academic Journal of Human Resource and Business Administration, 3(3), 218-242.

Montgomery, C. A., \& Wernerfelt, B. (1988). Diversification, Ricardian rents, and Tobin's q. The Rand journal of economics, 623-632.

Mudavadi, C., \& Weber, C. (2013). Safaricom Kenya Ltd: 2000 to 2010. In 2013 Proceedings of PICMET'13: Technology Management in the IT-Driven Services (PICMET) (pp. 88-96). IEEE.

Mujeri, M. K., \& Younus, S. (2009). An analysis of interest rate spread in the banking sector in Bangladesh. The Bangladesh Development Studies, 1-33.

Mwega, F. M. (2009). Global financial crisis discussion series. Overseas Development Institute, 111.

Nepali, S. R. (2018). Income diversification and bank risk-return trade-off on the Nepalese commercial banks. Asian Economic and Financial Review, 8(2), 279-293.

Ng'ang'a, F. W. (2019). The effect of interest rate capping on profitability of commercial banks in Kenya. International Journal of Social Sciences Management and Entrepreneurship (IJSSME), 3(1).

Olaka, H (2017): The Capping Interest Rates Debate: Market Failure or Necessary Intervention? Presentation at the 25 th ICPAK Economic Symposium, 16thFebruary 2017 Chief Executive Officer, Kenya Bankers Association

Olarewaju, O. M. (2018). Income Diversification in Low Income Sub-Saharan African Countries' Commercial Banks: A “Blessing" or "Curse"?. Folia Oeconomica Stetinensia, 18(2), 90-105.

Ovi, N. Z., Perera, S., \& Colombage, S. (2014). Market power, credit risk, revenue diversification and bank stability in selected ASEAN countries. South East Asia Research, 22(3), 399-416.

Paelo, A. (2014). Mobile money: taking on the big banks. CCRED Quarterly Competition Review, 10

Psillaki, M., \& Mamatzakis, E. (2017). What drives bank performance in transitions economies? The impact of reforms and regulations. Research in International Business and Finance, 39, 578-594

Pucheta-Martínez, M. C., \& Bel-Oms, I. (2019). What have we learnt about board gender diversity as a business strategy? The appointment of board subcommittees. Business Strategy and the Environment, 28(2), 301-315.

Rushdi, M., \& Tennant, J. (2003). Profitability of Australian Banks: 1985-2001. Agenda: A Journal of Policy Analysis and Reform, 229-243.

Sanya, S. and Wolfe, S.. (2011). Can Banks in Emerging Economies Benefit from Revenue Diversification?. Journal of Financial Services Research. 40: 79- 101.

Saunders, A., Schmid, M., \& Walter, I. (2016). Non-Interest Income and Bank Performance: Does Ring-Fencing Reduce Bank Risk? (No. 1417). University of St. Gallen, School of Finance.

Saunders, M. N. (2011). Research methods for business students, 5/e. Pearson Education India

Schoenmaker, D., \& Wagner, W. (2011). The impact of cross-border banking on financial stability (No. 11054/2/DSF18). Tinbergen Institute Discussion Paper. 
Shih, C. H., Wu, C. C., \& Yang, T. H. (2018). Diversification, Internal Capital Market, and Information Advantage

Sikod, F., \& Baye, M. (2015). Microfinance Access and Poverty Reduction in Cameroon. La microfinance en Afrique centrale: Le défi des exclus, 253.

Sufian, F., \& Chong, R. R. (2008). Determinants of bank profitability in a developing economy: empirical evidence from the Philippines. Asian Academy of Management Journal of Accounting \& Finance, 4(2).

Sun, S. T., \& Yannelis, C. (2016). Credit constraints and demand for higher education: Evidence from financial deregulation. Review of Economics and Statistics, 98(1), 12-24.

Toms, S., Wilson, N., \& Wright, M. (2019). Innovation, intermediation, and the nature of entrepreneurship: A historical perspective. Strategic Entrepreneurship Journal.

Tongurai, J., \& Vithessonthi, C. (2018). The impact of the banking sector on economic structure and growth. International Review of Financial Analysis, 56, 193-207.

Valla, N., Saes-Escorbiac, Beatrice \& Tiesset, Muriel. (2006). Bank liquidity and financial stability. Banque de France Financial Stability Review, 9, 89-104

Van Vu, H., Tran, T. Q., Van Nguyen, T., \& Lim, S. (2018). Corruption, types of corruption and firm financial performance: New evidence from a transitional economy. Journal of Business Ethics, 148(4), 847-858

Wan, G., \& Zhang, Y. (2018). The direct and indirect effects of infrastructure on firm productivity: Evidence from Chinese manufacturing. China Economic Review, 49, 143-153.

Waweru, N. M., \& Kalani, V. M. (2009). Commercial Banking Crises in Kenya: Causes and Remedies. African Journal of Accounting, Economics, Finance \& Banking Research, 4(4).

Williamson, S. D. (1986). Costly monitoring, financial intermediation, and equilibrium credit rationing. Journal of Monetary Economics, 18(2), 159-179.

Winton, A. (1997). Competition among financial intermediaries when diversification matters. Journal of Financial Intermediation, 6(4), 307-346.

Zikmund, W. G., Babin, B. J., Carr, J. C., \& Griffin, M. (2013). Business research methods. Cengage Learning. 